\title{
The communication of psychiatry in Brazilian press (1930-1940)
}

\section{Carolina Carvalho and Cátia Matias and Sérgio Marcondes}

\begin{abstract}
As a case study, we analyze an article of the psychiatrist Henrique Roxo published in 1942 in two publications directed to different publics. The communication of science was intended as part of Brazil's modernizing project of the epoch. Roxo's case reveals that the language used by science communicators, although sometimes of difficult apprehension, was part of an strategy of acknowledgment of the medical authority for the diagnosis and treatment of the mental illnesses.
\end{abstract}

Keywords

Health communication; Popularization of science and technology; Science writing

Introduction

This article aims to discuss the processes of communication and circulation of medical-psychological knowledge in Brazil during the 1930s and 1940s. As a case study, we used an article by the psychiatrist Henrique Roxo, published in 1942 in both a journal aimed at a specialised audience, the Arquivos Brasileiros de Higiene Mental (The Brazilian Archives of Mental Health), and in a variety magazine aimed at the general public, Vamos Ler! (Let's read!). Narrating the history of psi knowledge through its circulation among different audiences brings to the fore the diversified appropriations of its theories, allowing us to observe relevant factors such as the medium where the authors write, the audience for whom the authors write and their experience.

In addition, it is important to consider how political and social contexts interact with the production, reception and/or circulation of this knowledge. The 1930s and 1940s, for example, were marked by major changes in the circulation and communication of medical theories. In the international arena, the Second World War (1939-1945) had repercussions not only on diplomatic alliances but also on transnational scientific exchanges. In this way, the significant influence exercised by Germany on Brazil until the 1930s gave way to an official diplomatic break-up between these countries in 1942, followed by a 'permanent bargaining policy' in Brazil with the United States [Moura, 1991, pp. 8-9]. Such political, economic and military arrangements had important consequences on the national scientific scenario.

Psychiatry is a good example to observe the impact of these transnational rearrangements about the production of scientific and intellectual knowledge. 
While the first three decades of the 20th century were marked by the predominant influence of German organicism, which had been developed by Emil Kraepelin (1856-1926) as a classificatory model of mental illness [Facchinetti and Muñoz, 2013], since 1940, especially after the break down of the relation between Germany and Brazil, this scientific framework gradually disappeared from medical articles, giving rise to the North American theories including authors like Adolf Meyer (1866-1950).

At a national level, Brazil experienced an effective process of political-institutional centralisation that stood out, among many things, for the implementation of public policies about health and education, considered as fundamental pillars of the national project then sought by the government of Getúlio Vargas (1930-1945) [Hochman, 2001; Fonseca, 2007]. Despite the divergences between proposals and paths aimed at ensuring the modernisation of the nation, ${ }^{1}$ psychiatry stood out among the other fields of knowledge as the subject that challenged the vanguard of these modernisation projects [Muñoz, 2015]. Health was considered as a guarantee of progress on the basis of a consensus among physicians such as Renato Kehl, Júlio Porto-Carrero and Henrique Roxo that being modern was synonymous with being healthy and normal [Cupello, 2013, p. 50]. The progress of the Brazilian nation would be measured by the physical, moral, and mental strength of its people, making it necessary to defend the country against anything that might represent a threat to the health of its people and their descendants. Among these threats was the belief that mental illness was hereditary, which grounded psychiatrists' argument about the need to expand their work beyond mental health institutes to take care not only of sick individuals but also of those at risk of getting sick [Brasil, 1927]. This justified a set of medical interventions through prophylactic and eugenic measures.

Thus, some prophylaxis and health measures discussed and implemented during the First Republic were incorporated into the guidelines of the Ministry of Education and Public Health (MESP), created in 1930. Among them, there was the creation of courses for the training and specialisation of health professionals [Santos and Faria, 2006, p. 293] such as specialisation courses in psychiatry provided by the Institute of Psychiatry of the University of Brazil (IPUB) since $1929 .^{2}$ The themes presented in the activities carried out at the IPUB were in line with international debates, especially with regard to psychiatric models and classifications.

Since health and education fell under the responsibility of the same ministry, the need to train health specialists was complemented by the communication of science to non-expert audience, which was considered as a strategy to promote healthy behaviours and habits for the Brazilian people [Sá, 2006]. Thus, health professionals organised a series of campaigns against the mental, moral and

\footnotetext{
${ }^{1}$ Throughout the 19 th century the discussion about the national identity was affected by racial and deterministic theories that questioned the possibilities of a healthy and modern nation in a country with "mixed" and "degenerate" people [Schwarcz, 1993; Stepan, 2005]. It then underwent a discursive turn in the 20th century, with the emergence of the sanitary and hygienist movement, which disseminated the cure of backwardness and illnesses on the basis of sanitation and education [Lima and Hochman, 1996].

${ }^{2}$ The first specialisation course aimed only at physicians was held in 1929 by the substitute professor of Neurology and Psychiatry Clinics Faustino Esposel (1888-1931) at the Faculty of Medicine in Rio de Janeiro. His courses took inspiration from the courses he had attended during his staying in Europe ['Um curso de aperfeiçoamento na Faculdade de Medicina: fala-nos a respeito o seu organizador o professor Espozel' 1928].
} 
physical illness of the population, aiming to reach the general public in urban social layers. This effort was also attended by other stakeholders such as journalists, writers and intellectuals who, with relative authority as men of science or opinion makers, contributed to the circulation of medical knowledge outside scientific societies and academia.

When discussing health and illness in journals and variety magazines, these individuals also sought to advise their readers about behaviours considered healthy or pathological, adequate or correctable, disciplining and regulating people. The transposition of the medical discourse to a non-specialised audience aimed to educate and instruct the general public, but also to emphasise the authority of health professionals for issues involving prophylaxis and treatment. However, it encountered some obstacles, given the language used by doctors and their peers in the communication of this knowledge.

Between science communication and science communication: language and public
The circulation of scientific knowledge was limited by two issues: specialisation and medical language. With regard to communication, national and international congresses served as spaces for exchange and debate between doctors and scientists, sharing information about trends in the field. This interaction stimulated the circulation of scientific theories and the exchange increased the opportunity for new concepts, practices and techniques being incorporated into the existing local repertoire. It was a way of replicating knowledge, since accepted ideas were disseminated by scientists in their places of origin.

The results of the research and debates held at scientific congresses were widely disseminated in specialised books and journals, valued by scientists in the face of the need for "quick and precise communication about a specific experience or observation" and a "swift exchange of ideas and criticism among all scientists interested in the subject in question" [Mueller, 2000, p. 73]. Thus, the Brazilian psychiatric press experienced a period of growth in the first half of the 20th century, with the appearance of the Arquivos de Psiquiatria, Neurologia e Ciências Afins (Archives of Psychiatry, Neurology and Related Sciences) (1905), Arquivos Brasileiros de Higiene Mental (Brazilian Archives of Mental Hygiene) (1925), Boletim de Eugenia (Eugenia Bulletin) (1929), Arquivos do Manicômio Judiciário do Rio de Janeiro (Archives of the Judicial Asylum of Rio de Janeiro) (1930), and the Anais do Instituto de Psiquiatria (Annals of the Institute of Psychiatry) (1942). Besides contributing to the communication of scientific research, these journals became a space for dialogue and partnerships between psychiatrists who dealt with similar issues, also contributing to the recognition and professional advancement of the individual before their peers, creating networks of scientific communication.

Within the context of the debates, the national standardisation of concepts and classifications, linked to intellectual specialisation and statistical models, was a fundamental point [Sá, 2006, pp. 121-122]. By creating patterns that were pre-established and accepted by the psychiatric community, the communication of ideas was expanded, as more specialists would share that language, therefore reducing obstacles in the understanding of texts. This proposal also went through the teaching and training of physicians, so that they could log their work in order to reflect, since then, on the use of that theoretical-clinical model. 
The analysis of journalistic material related to a part of the intellectual production of the teaching staff of the Psychiatric Clinic of the Faculty of Medicine of Rio de Janeiro, mostly taught by professor Henrique Roxo, shows that these guidelines, however, were not followed to the letter. On the contrary, medical texts lacked clarity and had spelling mistakes. This was the conclusion of the literary critic Júlio Dantas (1876-1962), in an article published in Correio da Manhã, referring to the book Novidades em Doenças Mentaes (Novelties in Mental Diseases) published in 1934 by Atlântida Editora. The lecturer of Psychiatric Clinic of the FMRJ, Inaldo de Lyra Neves Manta (1903-2000), organised a list of the themes presented by several lecturers of the specialisation course in psychiatry taught the previous year. According to the critic, despite the good initiative in publicising "this interesting series of conferences" in the field of neurology and psychiatry, the work lacked a clear and objective wording, since "medicine is a science that makes up words when it has difficulty explaining the facts" [Dantas, 1934, p. 4]. He also noticed the careless and uncoordinated incorporation of French, German and Italian terms by the experts and the lack of orthographic and morphological standardisation of terms used in academic work. In this way, the use of foreign terms and specialised language often made the text unclear for the non-experts, keeping only the psychiatrists themselves informed and making access to information difficult.

Despite these difficulties, it is worth considering the role of the press in general as an instrument for disseminating ideas about health and hygiene interventions [Luca, 2005, p. 120]. In addition to the medical journals, there were also several other printed content that, committed to the efforts of moral and mental hygiene of the Brazilian population and aimed at the general public, acted in an educational and pedagogical way such as the Revista Nacional de Educação (National Journal of Education) (1932-1934). This journal was published by the National Museum and its proposal was to "to take science from the exclusive domain of the wise men to give it to the people". ${ }^{3}$ Not only journals, but also pamphlets, newspapers and books were illustrative and illustrated examples of the combination of medical and educational efforts, since they were intended to instruct their readers and provide them with information about illnesses for preventive purposes [Bertoletti, 2006].

While the number of magazines and printed content increased, several initiatives took place with the aim to broaden the scope to broaden the scope of research and improve the communication of science in Brazil. Until the first decades of the 20th century, the communication of science ${ }^{4}$ in Brazil was sporadic and poorly consolidated. This scenario began to change with events such as the foundation of the Sociedade Brasileira de Ciências (Brazilian Society of Sciences) in 1916, which would later become the Academia Brasileira de Ciências (Brazilian Academy of Sciences) in 1922. Its president was the French naturalised Brazilian Henrique

\footnotetext{
${ }^{3}$ Funded by MESP, the magazine was run by the anthropologist and writer Edgard Roquette-Pinto (1884-1954) and distributed free of charge in prefectures, schools and various cultural and class associations. The articles were written by specialists, they were short and didactic. By being "tuned in to the ideal of a state whose pedagogical action formed a people and a nation", its publication was part of an effort to establish a dialogue between the government and the population [Duarte, 2004].

${ }^{4}$ In France, unlike Brazil, nowadays "vulgarisation", not "communication", is the term most commonly used to refer to "any activity of science communication aimed for the general public" without having pejorative characteristics. In other languages such as English, the terms "popularisation" and "communication" have become more common [Bensaude-Vincent, 2010, pp. 2-4]. In Brazil, during the 19th century and the first decades of the 20th century, "vulgarisation" was also the most commonly used term [Moreira and Massarani, 2002, pp. 50-51].
} 
Morize (1860-1930), an engineer specialised in training who published science communication articles in various journals. This same academy created Rádio Sociedade ${ }^{5}$ in 1923, the first Brazilian radio which had in its programming courses and lectures of science communication on various subjects [Moreira and Massarani, 2002, pp. 50-53].

Despite the acknowledged increase in "collections of science vulgarisation books" in Brazil, some scientists were not convinced of the "usefulness of bringing the general public abreast of the scientific movement", as Dr Miguel Osório de Almeida (1890-1953) pointed out in an article in 1931. According to him, however, there was no doubt about this usefulness, as "well-oriented instruction of the population is done in a way that leaves no doubt as to the effective competence of those who have acquired it" and therefore "well-conducted science popularisation has as real end that of clarifying more than teaching in detail about a specific topic" [Almeida, 2002 [1931], pp. 65, 68]. Almeida concluded his article showing great optimism about the advantages of disseminating science to the general public:

On the day when the majority of men are impregnated with the true meaning of the ends of science, and have grasped a little of the essence of scientific methods, and at a later stage, know whether to explore a little bit the advantages of scientific culture, for the precision it provides to the reasoning and for the respect for the truth, besides other moral qualities it develops, mankind will have taken a significant step forward [Almeida, 2002 [1931], pp. 69-70].

Based on health and education, the communication of science to a general public was presented with the purpose of educating this audience, which was made up of an urban population uneducated in medicine. Even the issue of reading presented itself as an issue for mental health, which emphasised the importance of healthy readings for people's health. This incentive was also linked to the formation of a literature consumer market. ${ }^{6}$ The illustrated magazine Vamos Ler! is an example of this commitment, where encouragement to reading is expressed in the title itself.

Vamos Ler!: an example of science communication
Published weekly by Sociedade Anônima A Noite, the magazine Vamos Ler! (1936-1948) had national reach. The A Noite was a large publishing company, which also published the newspapers $A$ Noite e $A$ Manhã, the magazines Sintese, Carioca and Noite Ilustrada, besides being responsible for the National Radio, founded in 1936. In 1940 the whole group of the Sociedade Anônima was formally expropriated by the Vargas government and became part of the Empresas Incorporadas ao Patrimônio Nacional (Companies Incorporated to the National Patrimony) [Brasil, 1940].

Adopting reading as the main motto, the magazine aimed to entertain and educate its audience. In order to do so, it disseminated literary novelties, besides

\footnotetext{
${ }^{5}$ About Rádio Society, see the website available on the Fiocruz Portal: http://www.fiocruz.br/radiosociedade/cgi/cgilua.exe/sys/start.htm?tpl=home.

${ }^{6}$ It is worth noting that the 1930s and 1940s were marked by an unprecedented growth of the Brazilian book publishing market, both for publications of translated foreign works and for originals in Portuguese [Hallewell, 2012, pp. 464-465, 846-847].
} 
addressing national and international politics, educational and pedagogical discussions, cinema, radio, psychology, fashion, palmistry, astrology and others in order to reach a large number of readers among the literate layers of society. Its proposal also revealed the commitment to contribute to the "raising of the race" ['Convite à leitura' 1936, p. 3] and to "the education of the Brazilian Youth" [Mello, 1940, p. 25], getting closer to the educational measures undertaken by MESP under the management of Gustavo Capanema. The search for the construction of a solid culture linked to moral and civic education and patriotism guaranteed investment in cultural manifestations [Gomes, 2000], as in literature.

Although the circulation of Vamos Ler! during its period of publication is not known, we know that about 40,000 copies were sold [Mello, 1941, p. 36]. The presence of themes of popular appeal encouraged the participation of its readers, who, promoted to collaborators, had their letters published and received awards for several subjects. The journal's engagement with education and science communication for the general public was expressed, for example, through sections dedicated to informing about and clarifying medical doubts, such as 'Novidades Médicas' (Medical News) and 'Página do Farmacêutico' (Pharmacist's Page). In addition, it promoted educational and pedagogical debates among those readers who worked as educators, as in the column 'Estudos, colas e...colações' (Studies, notes and... collations). It shared the experiences of readers who worked in schools, as well as statements of Minister Capanema and President Getúlio Vargas on the importance of making teaching and citizenship universal to guarantee the nation's progress.

Among the authors who contributed to the communication of medical-mental knowledge in Vamos Ler!, the psychoanalyst Gastão Pereira da Silva (1898-1987) ${ }^{7}$ stands out. As a precursor of the communication of psychoanalysis to non-experts, Gastão worked on the sidelines of both academic institutions such as the Liga Brasileira de Higiene Mental ${ }^{8}$ (Brazilian League of Mental Hygiene) and the psychoanalytic societies that were set up in that period, which did not prevent him from writing several books and collaborating in a large number of means of communication [Marcondes, 2015].

In Vamos Ler!, Gastão collaborated in sections such as 'Uma página para as mães' (A page for mothers), 'Psicologia da vida quotidiana' (Psychology of everyday life), 'Doentes célebres' (Famous patients), 'Vida amorosa dos animais' (Loving lives of animals), 'Criminosos célebres' (Notorious criminals) and 'A guerra através da biografia' (War through biography), where he taught the public techniques of self-analysis and the postulates of psychoanalysis. ${ }^{9}$ These sections reveal how

\footnotetext{
${ }^{7}$ Gastão Pereira da Silva (1898-1987) was born in Rio Grande do Sul or Rio de Janeiro (there is no agreement among the sources). He worked as a doctor in small towns before settling down in Rio de Janeiro in the 1930s. Since then, he published several works for the communication of psychoanalysis, as well as writing in magazines of great circulation and attending patients in the office. In 1934 he received a letter from Freud encouraging him to continue his efforts to popularise psychoanalysis in Brazil, which he frequently used as a source of legitimation [Marcondes, 2015].

${ }^{8}$ The Brazilian League of Mental Hygiene was founded in 1923 by the psychiatrist Gustavo Riedel (1887-1934), working together with society on proposals and campaigns linked to eugenic principles and mental hygiene.

${ }^{9}$ It is worth mentioning that psychoanalysis was already widespread in Brazil in the 1910s and 1920s in academic circles and also served the prophylactic purposes proposed by mental medicine. It
} 
much the author sought to relate the most varied subjects to psychoanalysis, using a didactic and understandable writing style. Many of these columns continued to be used in their later communication efforts, giving rise to books like 'Conheça seu filho' 'Know your child', published by the A Noite publishing house in 1942, which took took up 'Uma página para as mães' again. The column 'Criminosos célebres', in which he dealt with the relations between criminology and psychoanalysis, continued a discussion that had started with his book 'Crime e psicanálise' (Crime and Psychoanalysis) in 1933 [Silva and Silva, 1933; Marcondes, 2015, pp. 105-106].

Another physician - academically recognised - published in Vamos Ler!: the psychiatrist Henrique Roxo (1877-1969). ${ }^{10}$ In 1942 Roxo introduced readers to a set of clues on how to diagnose mental illness. The highly specialised language used in his text takes the distance from the magazine's proposal to educate its readers. However, it allows us to glimpse the importance given by the author to medical authority in the treatment of psychopathologies, which becomes even clearer when we think of his place of speech: the University of Brazil, one of the most traditional places for scientific production in the country, where he worked as a professor at the Psychiatric Clinic and director of the IPUB.

Henrique Roxo and the directions of psychiatry in the 1940s
In the 1940s professor Henrique Roxo was a well-known and respected person in the Brazilian scientific and academic environment. After nearly forty years of teaching, he had contributed to the professional training of numerous Brazilian psychiatrists. He had participated in national and international events and travelled in order to acquire new knowledge and spread the practice and teaching of psychiatry.

At that time, he had a vast list of published works - about 130. His books, articles and congress papers presented research results and observations carried out within the institution where he had always taught and done research - the Pavilhão de Observação (Observation Pavilion), later renamed as the Institute of Psychiatry of the University of Brazil (IPUB). In the first decades of his career, he was affiliated with the French alienism, spread by the Faculty of Medicine of Rio de Janeiro, where he was a professor of psychiatric clinical practice. It is possible to observe that from the 1920s the incorporation of the precepts of German psychiatry in the daily life of the Pavilion as well as in its academic production. Both theories were widely disseminated by Roxo in scientific journals.

In 1939, this professor gave an interview to Jornal do Brasil, where he expressed the importance of the integration of the assistants in the institutional research, mentioning that in the IPUB he had implemented similar practices to those developed in Germany and the United States. In addition, he stated that research in the USA was highly valued, so much so that a Hungarian professor, Ladislas J. von

was one of the many subjects triggered by the project of moral pedagogy and mental hygiene that created relations between morality, biological issues and modernity, also considered by Henrique Roxo in his reflections on the origin of mental illness [Facchinetti and Venancio, 2006].

${ }^{10}$ Henrique de Britto Belford Roxo (1877-1969) was born in Rio de Janeiro. He graduated from the Medical School of Rio de Janeiro in 1901 and twenty years later he became professor of Psychiatric Clinic at the same institution, as well as director of the Pavilhão de Observação do Hospício Nacional de Alienados (Observatory of the National Hospice of Alienated). In 1938 the institute was transferred to the University of Brazil, where Roxo then founded the Instituto de Psiquiatria (Institute of Psychiatry) (IPUB). He continued in these positions until he retired in 1945. 
Meduna (1896-1964), ${ }^{11}$ had been hired in that country for biochemistry research investigation related to the pathogenesis of schizophrenia ['Enaltecendo a obra de um grande mestre' 1939]. Despite the fact that the teaching and practice of Kraepelinian German psychiatry were present, he emphasised how close they were to the North American psychiatric school, which was already outlined in the IPUB and would become more consolidated in the 1940s, after Brazil and Germany broke off their diplomatic relations.

Roxo went to the United States twice: in 1929, at the 9th International Congress of Psychology held in New Haven, Connecticut, and in 1940, at the 8th American Scientific Congress in Washington. On this last occasion, he received an invitation to attend conferences at the Universities of Chicago and Berkeley (San Francisco, California). In addition to the lectures, he visited the teaching and research departments at the Psychiatric Clinic in New York, the University of Michigan and the clinical hospitals in Chicago and Los Angeles. Taking advantage of this opportunity, he visited the League of Mental Hygiene of New York as representative of the Brazilian counterpart, being received by the neuropsychiatrist and professor George S. Stevenson (1892-1983), president of that society. During the meeting, he said that he regularly sent the journal Arquivos Brasileiros de Higiene Mental to the North American society. The president of the American league, however, declared that he did not know the Portuguese language and therefore could not read the Brazilian magazine. He then suggested that each article in this journal should present a summary in English so that it could be understood by American readers ['Professor Henrique Roxo: as homenagens que lhe foram prestadas ontem pela classe médica' 1940, p. 4]. Roxo's initiative in disseminating Brazilian psychiatric science to his American counterparts therefore ran up against a language barrier. On his return, he told the Gazeta de Notícias that the US education and research had a good infrastructure and received large sums of money that contributed to improve their quality even more ['A Sciencia psiquiátrica nos Estados Unidos' 1940, p. 9]. He compared this to the harsh Brazilian reality, where the funds allocated to research were scarce and the buildings in which this activity was carried out were old and poorly equipped.

In the 1940s, some Brazilian psychiatrists sought training in North America, for example, Dr Iracy Doyle Ferreira (1911-1956), former intern and assistant for the Psychiatric Clinic and lecturer at the Faculty of Medicine. She was awarded a scholarship to study the abnormal childhood at the neuropsychiatric clinic of John Hopkins University through a contest which saw the participation of South American doctors. She returned to Brazil in 1946 and founded the Clinica de Repouso (Rest Clinic) in Tijuca on the basis of the clinic of the brothers Karl Menninger (1893-1990) and Will Menninger (1899-1966), located in Kansas. In the same year, Iracy returned to the United States, this time to specialise in psychoanalysis, at the William Allanson White Institute, New York ['Faleceu ontem a dra. Iracy Doyle: um dos nossos maiores valores no campo da psiquiatria' 1956, p. 4].

\footnotetext{
${ }^{11}$ Professor Meduna had emigrated to the United States in 1938, fleeing Nazism in Europe. Establishing himself initially as a professor at Loyola University in Chicago, he visited Brazil in 1939 invited by Adauto Botelho. In Rio de Janeiro, he lectured at the Society of Psychiatry, Neurology and Forensic Medicine, the National Academy of Medicine, the Society of Medicine and Surgery and the Neurological Clinic of the University of Brazil, as well as visiting the Colonia Juliano Moreira, the National Hospital of Alienated and the Botafogo Sanatorium. After fulfilling his schedule in Rio de Janeiro, Meduna went to São Paulo, where he stayed for another week, also giving lectures ['Está no Rio um grande psychiatra húngaro' 1939, p. 12].
} 
In this decade, Dr Amando Caiuby Novaes, ${ }^{12}$ assistant to professor Antônio Carlos Pacheco e Silva (1898-1988) at the Faculty of Medicine of the University of São Paulo (USP), published in the Arquivos de Neuro-Psiquiatria (Archives of Neuro-Psychiatry) (1947) the proceedings of a conference given the year before. This conference had been organised at the Associação Paulista de Medicina (Paulista Medical Association) and was about his impression of the specialisation he was awarded at the Neuro-Psychiatric Institute of the Hartford Retreat under the guidance of Dr Cecil Charles Burlingame. ${ }^{13}$ In his article, he described the physical aspects of the hospital, as well as the psychiatric practices, treatments and medical examinations that most caught his attention during the period in which he studied at that hospital and later during his scientific trip through that country. Novaes also pointed out the enthusiasm of the Americans for treatments based on convulsion therapy - electroshocks, use of cardiazol and insulin. In addition to these therapies, he described the use of other techniques and medications most used, for example hypnotism, leucotomy, group psychotherapy, or curare $^{14}$ and penicillin use.

The Second World War brought some significant transformations in the field of sciences in the country, with a substantial increase of the North American influence. The same occurred at the IPUB, mainly in what concerns the acquisition of the theoretical framework that laid foundation of studies and research in that environment. The war also affected the international publishing market, making it difficult to import bibliographical material of European origin. Based on the archive $^{15}$ of the IPUB library referring to this period, we noticed a considerable increase in the acquisition of American and Argentine books compared to European literature. In the 1940s, 143 books were purchased from the United States, 95 from Argentina and 54 from Europe (36 from France, 16 from England and 2 from Germany). In the previous decade, 24 books had been imported from the United States, 14 from Argentina and 31 from France. ${ }^{16}$ In terms of journals subscription, we noticed that the subscription to the American Journal of Psychiatry and the Psychiatric Quarterly started in 1938, the one for the Revista de Neuro-Psiquiatria (Lima) in 1939, the one for the Journal of Nervous Mental Disease in 1940, that to the Revista de Psicoanalisis (Argentina) in 1943 and that to Psychoanalytic Study of the Children in 1945.

According to what was found, it was in the 1940s that Brazilian and American specialists became increasingly closer, supported by the social, political and economic changes brought about by the world conflict. Physicians such as those

\footnotetext{
${ }^{12}$ No dates of birth and death of this physician were found in the sources consulted.

${ }^{13}$ Dr. Burlingame offered this scholarship to one of Professor Pacheco e Silva's assistants. Novaes states that "it was therefore the name of Pacheco e Silva and the fair prestige he enjoys in the scientific circles of the United States, particularly among the most renowned psychiatrists of that country, who took us to Hartford in order to improve knowledge here acquired with that Master" [Novaes, 1947, p. 167].

${ }^{14}$ Substance of vegetable origin that has a paralyzing action, which can lead to death by asphyxiation if the amount of substance injected is high. This drug was clinically used in neuropsychiatry [Silva Jr, 1945].

${ }^{15}$ Specific book where the whole collection of a library is registered, representing its bibliographic asset. The bibliographic record of the IPUB library began in 1949.

${ }^{16}$ As the IPUB administrative documents are not available, we do not have any data to analyse the significant difference between the number of books acquired in the 1930s and 1940s. This may have been caused by an increase in the amount stipulated for this purpose, after the Second World War, or because the books acquired in the 1930s were lost, since control of the bibliographic collection began in 1949.
} 
mentioned above sought to qualify with renowned specialists in specialised American hospitals. When they returned to their home institutions, they implemented models which were aligned with the newly acquired concepts and psychiatric practices. Participation in scientific events also contributed to the exchange of knowledge and the acquisition of a new theoretical and technical information highlights the concern of IPUB psychiatrists to be up-to-date with new scientific concepts and therapeutics such as convulsion therapies. Thus, although the psychiatrists of the 1940s still mentioned the Kraepelian concept and even the moral treatment, new references from the United States began to appear in the debates on the topics that were considered relevant and current in the area.

Who has the authority to talk about science?
In 1942 Henrique Roxo published the article 'Você pode diagnosticar uma doença mental' (You can diagnose a mental illness) in Vamos Ler!, where he summarised his ideas, whereby it would be possible to identify some signs indicating the presence of psychopathologies that may need medical intervention and specialist help would be required by the population in difficult access situations [Roxo, 1942b]. The text had originally been published a few months earlier in the Arquivos Brasileiros de Higiene Mental and was entitled 'Como diagnosticar uma doença mental' (How to Diagnose a Mental Illness) [Roxo, 1942a, p. 28]. By comparing and contrasting the two texts, we found that, except for the slight change in the title, the content was identical, although the journals where they were published had different types of audience; the Arquivos Brasileiros de Higiene Mental was dedicated to the scientific community, whereas Vamos Ler! aimed at scientific and literary communication for the general public.

Roxo began his article by arguing that the perception of mental illness was not always so obvious: "it may be that an alienated man will conceal his illness, and the specialist will need all their skill and scientific knowledge to discover the truth" [Roxo, 1942b, p. 22]. When describing the symptoms of various psychic disorders such as alcoholism, drug addiction, epilepsy, paranoid syndrome, hysteria, melancholy, the psychiatrist pointed to the typical manifestations of diseases, as well as some subtle differences among the various nosological categories that only a specialist would be able to identify. Even so, the 'sanity certificate' should not be given in a rushed way, justifying in some cases the hospitalisation: "you must carefully examine, several times, the suspected mentally ill. In order to do it better, at times you need to seek hospitalisation in an institution for the alienated" [Roxo, 1942b, p. 28].

The family was a point of conflict, because in many cases "it is not only the patient; their family, interested in their relative not being considered as mentally ill, seeks to mislead the psychic disorders" [Roxo, 1942b, p. 28]. This brought to light not only the social stigmas caused by stereotypes related to the disease, but reinforced how important the physician was in the diagnosis. This is one of the central themes of the article and is quite revealing of the disciplinary and normative approach that the magazines took when participating in the discussion about behaviours considered as normal and/or deviant. Although in the case of non-specialised magazines this approach has occurred more through suggestions and advice in sections relying on readers' participation, the publication of Henrique Roxo in Vamos Ler! provided some clues about psychiatry's efforts to care not only for the inpatients but also for those who were at risk of becoming ill. 
On the other hand, family members, teachers, heads of service among others, had a role in the diagnostic process as collaborators to the doctors. After all, the text underlined the importance of "behavioural anomalies of a person" as characteristics of "the existence of a mental illness". This perspective made the family mostly a potential support for psychiatry, in line with the American psychiatric model proposed by Adolf Meyer. ${ }^{17}$ According to this framework, the patient's constitution in relation to their family and social environment was more important than the biological and hereditary predisposition.

This means that psychobiology, which focused on the interrelationship between symptoms and psychological and biological functions of the individual, kept from the German organicism the analysis of the biographical direction as a fundamental element for the identification, treatment and cure of mental illnesses. However, according to Meyer it was a matter of comparing and contrasting the behaviours prior to the manifestation of the pathology with the behaviours after the diagnosis and the intervention, whereas Kraepelin gathered data on the evolution of the diseases in the individuals through the diagnostic cards (Zählkarten), where up-to-date information about the patient was logged over time, even after discharge or transfer to other medical institutions [Muñoz, 2015, p. 57].

Another reliable way to identify the diagnoses, in Roxo's opinion, were the indispensable laboratory tests, since "there are cases where the clinical symptoms are so blurred that only laboratory tests can clarify them" [Roxo, 1942b, pp. 32-33]. In addition, the anamnesis was certainly linked to clinical observation. Throughout the text, Roxo repeated several times the importance of observing the behaviour of individuals under suspicion of mental illness: "it is seen that an individual is a mental patient, by their behaviour, by their way of feeling or saying"; "sometimes there is not a delusional theme, but there is a state of excitement or restlessness." Finally, he emphasised that "the psychiatrist must [...] carefully observe the way in which [the patient] feels, thinks and acts" [Roxo, 1942b, pp. 35-36].

In the case of children, Roxo drew attention to the subtle differences between illness and educational errors that resulted in a child's mental imbalance, and "behaviour and teaching" should be observed. Organic alterations, such as "calcium metabolism disturbances" and "disorders of internal secretion glands," and hereditary diseases such as syphilis were often confused with poor education. Again, the author reinforced the need for the presence of a specialist, an authority capable of observing and comparing changes in child behaviour, and making the necessary examinations [Roxo, 1942b, p. 35].

In summary, the text demonstrates that the task of diagnosing a patient was of "enormous responsibility", since such an assessment had an impact on the patient's individual freedom, which also influenced the management of their own assets. In spite of the long-winded language, Roxo's intention was expressed clearly: to reinforce medical authority in the diagnostic process, justifying the necessity to put

\footnotetext{
${ }^{17}$ Adolph Meyer (1866-1950) was a Swiss psychiatrist and neurologist who built an academic career in the United States. His psychiatric model contrasted with Emil Kraepelin's psychiatric theories, based on organicism. He advocated psychobiology in therapeutic treatment, arguing that psychopathology was the product of a number of factors - environmental, social, physical and moral - that, combined with patient personality, would provide a "practical guide" to the disease and allow for an individualised therapy (http:/ / www.psiquiatriageral.com.br/psicoterapia/adolf.htm).
} 
the individual suspected of mental illness in observation, and, in the case of the positive diagnosis, to indicate the patient's hospitalisation. Even though it presented clues for the general public - relatives and teachers - to identify an individual suspected of suffering from mental issues, this would serve to refer them to a doctor's practice, reiterating the psychiatrist's sole responsibility for producing a diagnosis.

When compared to the publications by other authors who acted as "men of science" in Vamos Ler!, such as Gastão Pereira da Silva, the article by Henrique Roxo seems incompatible with the proposals of science communication adopted by the magazine. Having written a highly specialised and refined text, a feature observed and commented upon by the literary critic Júlio Dantas, the professor and psychiatrist did not fully clarify the diagnoses to his readers, although he provided detailed characteristics about the symptoms of the diseases.

However, this may be understood as part of Roxo's intention to publicise psychiatry in a magazine dedicated to a non-specialist audience. Presenting such specific and detailed knowledge may lead one to glimpse his intention to demonstrate that non-experts should be alert to the signs of behavioural change in their relatives and other people of close coexistence, being able to act as helpers of the specialists. On the other hand, such signs and symptoms could only be validated through a diagnostic process created by an expert capable of classifying them: the psychiatrist, whose authority should be recognised and respected.

As a professor at the University of Brazil, director of IPUB and president of the Brazilian League of Mental Hygiene (position he held since 1938), Henrique Roxo asserted his position as a psychiatric authority. His career trajectory allows us to access the scenario of the production of knowledge and scientific exchanges that would interfere in the definition of what foreign knowledge would be in connection with the production of the national medicine. It is the example of the Brazilian and American psychiatry working increasingly closer to each other, which in turn reflects the alignment between Brazil and the United States, an exchange of which Roxo participated through congresses and trips.

Although the language used by Roxo does not seem as didactic as that of other physicians and scientists who wrote for the magazine, the issue of an article originally published in a specialised magazine — the Arquivos Brasileiros de Higiene Mental (Brazilian Archives of Mental Hygiene) — in a popular publication and engaged with the scientific communication as Vamos Ler! shows an effort by psychiatry to extend its borders beyond psychiatric institutions. One of the strategies implemented was the use of the press as an instrument of action, both in specialised and non-specialised journals.

More than the difficulty for physicians to speak clearly to those who did not share the canons of medicine and the reinforcement of the authority of a specialist for the diagnosis, Henrique Roxo's publication in Vamos Ler! brings to the fore the combination of efforts to reach the general public and mobilise it to prevent mental illness in dialogue with the public proposals of health of the time, that saw the pathology as an obstacle to the establishment of the normal nation that Brazil wanted to be. 
'A Sciencia psiquiátrica nos Estados Unidos' (3rd July 1940). Gazeta de Notícias. Rio de Janeiro, Brazil, pp. 9, 14.

Almeida, M. O. (2002 [1931]). 'A vulgarização do saber'. In: Ciência e Público: caminhos da divulgação científica no Brasil. Ed. by L. Massarani, I. Moreira and F. Britto. Rio de Janeiro, Brazil: Casa da Ciência - Centro Cultural de Ciência e Tecnologia da UFRJ.

Bensaude-Vincent, B. (2010). 'Splendeur et décadence de la vulgarisation scientifique'. Questions de communication (17), pp. 19-32. DOI: 10.4000 /questionsdecommunication. 368.

Bertoletti, E. N. M. (2006). Lourenço Filho e a alfabetização: um estudo de Cartilha do povo e da cartilha Upa, cavalinho! São Paulo, Brazil: Editora da UNESP.

Brasil (1927). Decreto $n^{0} 17.805$, de 23 de maio de 1927. URL: http:///www.ccs.saude.gov.br/saude_mental/legis/legis3.asp (visited on 5th June 2016).

- (1940). Decreto-lei no 2.703, de 8 de março de 1940. URL: http://legis. senado.gov . br/legislacao/ListaPublicacoes . action?id=41183 (visited on 4th November 2016).

'Convite à leitura' (6th August 1936). Vamos Ler! 1, p. 3.

Cupello, P. C. (2013). 'A mulher (a)normal: representações do feminino em periódicos científicos e revistas leigas na cidade do Rio de Janeiro (1925-1933)'. Dissertação de Mestrado em História das Ciências e da Saúde. Rio de Janeiro, Brazil: Casa de Oswaldo Cruz/Fiocru.

Dantas, J. (1st June 1934). 'Literatura psychiatrica'. Correio da Manhã, p. 4.

Duarte, R. H. (2004). “"Em todos os lares, o conforto moral da ciência e da arte”: a Revista Nacional de Educação e a divulgação científica no Brasil (1932-34)'. História, Ciências, Saúde-Manguinhos 11 (1), pp. 33-56. DOI: $10.1590 / \mathrm{s} 0104-59702004000100003$.

'Enaltecendo a obra de um grande mestre' (9th July 1939). Jornal do Brasil, p. 7.

'Está no Rio um grande psychiatra húngaro' (3rd June 1939). O Jornal, p. 12.

Facchinetti, C. and Muñoz, P. F. N. d. (2013). 'Emil Kraepelin na ciência psiquiátrica do Rio de Janeiro, 1903-1933'. História, Ciências, Saúde-Manguinhos 20 (1), pp. 239-262. DOI: 10.1590/s0104-59702013000100013.

Facchinetti, C. and Venancio, A. T. A. (2006). 'Entre a psicanálise e a degenerescência: sexualidade e doença mental no início do século XX no Brasil'. Revista Latinoamericana de Psicopatologia Fundamental 9 (1), pp. 151-161. DOI: $10.1590 / 1415-47142006001012$.

'Faleceu ontem a dra. Iracy Doyle: um dos nossos maiores valores no campo da psiquiatria' (19th August 1956). Correio da Manhã, p. 4.

Fonseca, C. M. O. (2007). Saúde no governo Vargas (1930-1945): dualidade institucional de um bem público. Rio de Janeiro, Brazil: Fiocruz.

Gomes, A. de C. (2000). Capanema: o ministro e seu ministério. Rio de Janeiro, Brazil: FGV.

Hallewell, L. (2012). O livro no Brasil: sua história. 3rd ed. São Paulo, Brazil: Edusp.

Hochman, G. (2001). 'A saúde pública em tempos de Capanema: continuidades e inovações'. In: Constelação Capanema: intelectuais e políticas. Ed. by H. Bomeny. Rio de Janeiro, Brazil: FGV, pp. 127-151.

Lima, N. T. and Hochman, G. (1996). 'Condenado pela raça, absolvido pela medicina: o Brasil descoberto pelo movimento sanitarista da Primeira República'. In: Raça, ciência e sociedade. Ed. by M. C. Maio and R. V. Santos. Rio de Janeiro, Brazil: Fiocruz/CCBB, pp. 23-40. 
Luca, T. R. de (2005). 'História dos, nos e por meio dos periódicos'. In: Fontes históricas. Ed. by C. Pinsky. São Paulo, Brazil: Contexto.

Marcondes, S. R. de A. (2015). "“Nós, os charlatães”: Gastão Pereira da Silva e a divulgação da psicanálise em O Malho (1936-1944)'. Dissertação de Mestrado em História das Ciências e da Saúde. Rio de Janeiro, Brazil: Casa de Oswaldo Cruz/Fiocruz.

Massarani, L., Moreira, I. and Britto, F., eds. (2002). Ciência e Público: caminhos da divulgação científica no Brasil. Rio de Janeiro, Brazil: Casa da Ciência - Centro Cultural de Ciência e Tecnologia da UFRJ.

Mello, A. V. de (15th August 1940). 'Vamos Ler! e a publicidade'. Vamos Ler! 211, p. 25.

- (29th May 1941). 'Nova fase'. Vamos Ler! 2, p. 45.

Moreira, I. and Massarani, L. (2002). 'Aspectos históricos da divulgação científica no Brasil'. In: Ciência e Público: caminhos da divulgação científica no Brasil. Ed. by L. Massarani, I. Moreira and F. Britto. Rio de Janeiro, Brazil: Casa da Ciência - Centro Cultural de Ciência e Tecnologia da UFRJ.

Moura, G. (1991). Sucessos e ilusões: relações internacionais do Brasil durante e após a Segunda Guerra Mundial. Rio de Janeiro, Brazil: FGV.

Muñoz, P. F. N. de (2015). 'À luz do biológico: psiquiatria, neurologia e eugenia nas relações Brasil-Alemanha (1900-1942)'. Tese de Doutorado em História das Ciências e da Saúde. Rio de Janeiro, Brazil: Casa Oswaldo Cruz/Fiocruz.

Mueller, S. P. M. (2000). ‘O periódico científico'. In: Fontes de informação para pesquisadores e profissionais. Ed. by B. S. Campello, B. V. Cendón and J. M. Kremer. Belo Horizonte, Brazil: Editora da UFMG, pp. 73-96.

Novaes, A. C. (1947). 'Aspectos práticos da psiquiatria norte-americana'. Arquivos de Neuro-Psiquiatria 5 (2), pp. 167-180.

'Professor Henrique Roxo: as homenagens que lhe foram prestadas ontem pela classe médica' (6th July 1940). Gazeta de Notícias. Rio de Janeiro, Brazil, pp. 4, 10.

Roxo, H. (1942a). 'Como diagnosticar uma doença mental'. Arquivos Brasileiros de Higiene Mental XIII (1), pp. 28-38.

- (1942b). 'Você pode diagnosticar uma doença mental'. Vamos Ler! 327, pp. 22-23, 61 .

Sá, D. M. de (2006). A ciência como profissão: médicos, bacharéis e cientistas no Brasil (1895-1935). Rio de Janeiro, Brazil: Fiocruz.

Santos, L. A. de C. and Faria, L. (2006). 'O ensino da saúde pública no Brasil: os primeiros tempos no Rio de Janeiro'. Trabalho, Educação e Saúde 4 (2), pp. 291-324. DOI: 10.1590/s1981-77462006000200005.

Schwarcz, L. M. (1993). O espetáculo das raças: cientistas, instituições e questão racial no Brasil, 1870-1930. São Paulo, Brazil: Companhia das Letras.

Silva, G. P. da and Silva, J. P. da (1933). Crime e psicanálise. Rio de Janeiro, Brazil: Livraria Editora Marisa.

Silva Jr, J. A. C. da. (1945). 'Aplicações do curare em neuro-psiquiatria'. Arquivos de Neuro-Psiquiatria 3 (4), pp. 467-471. DOI: 10.1590/s0004-282x1945000400010.

Stepan, N. (2005). A hora da eugenia: raça, gênero e nação na América Latina. Rio de Janeiro, Brazil: Fiocruz.

'Um curso de aperfeiçoamento na Faculdade de Medicina: fala-nos a respeito o seu organizador o professor Espozel' (18th November 1928). O Imparcial, pp. 3, 7. 
Carolina Carvalho is graduated in History by University of the State of Rio de Janeiro (UERJ) and research assistant in Casa de Oswaldo Cruz-Fiocruz.

E-mail: carolinaccarvalho@outlook.com.

Cátia Matias is graduated in Library Science and Documentation by University Federal Fluminense (UFF) and is an student of the Masters Program in History of Sciences and Health in Casa de Oswaldo Cruz-Fiocruz.

E-mail: maryska.m@hotmail.com.

Sérgio Marcondes is graduated in History by the University of São Paulo (USP), master in History of Sciences and Health in Casa de Oswaldo Cruz-Fiocruz, institution where is a student of the Ph.D. Program.

E-mail: serram2011@gmail.com.

The authors are researchers on the field of communication and popularization of the "psi" sciences in Brazil, under orientation of PhD professor Cristiana Facchinetti.

How to cite

Carvalho, C., Matias, C. and Marcondes, S. (2017). 'The communication of psychiatry in Brazilian press (1930-1940)'. JCOM 16 (03), A13_en. 